\title{
Effect of Chemical Treatments and Incorporation of Organic Matter on the Pathogenicity and Survival of Pseudomonas solanacearum (Smith) in Soil
}

\author{
J. M. R. S. BANDARA
}

Department of Agricultural Biology, Faculty of Agriculture, University of Peradeniya, Peradeniya, Sri Lanka

(Date of receipt: 13 June 1983)

(Date of acceptance: 10 December 1984)

\begin{abstract}
All solanaceous crops cultivated in Sri Lanka except chilli cv. MI 1 were found to be susceptible to biotype 3 of Pseudomonas solanacearum. Bacterium was also proven pathogenic to some of the improved cultivars of AVRDC tomato selections. Organic manure (chicken manure, cowdung, and Gliricidia leaves) when incorporated into inoculated soil significant increase in number of propagules of $P$. solanacearum and severity of wilt disease in subsequent tomato cv. marglobe were observed in contrast to chemical treatments (lime, acetic acid, Benomyl and Captan). Significant reduction of bacterial population and disease severity was seen in Captan and Benomyl treated soil only. Organic manure treatments stimulated growth of both $P$. solanacearum and other saprophytic bacteria. The ratio of $P$. solanacearum to other bacteria showed a direct relationship to percentage wilt in a subsequent tomato crop.
\end{abstract}

\section{Introduction}

The bacterial wilt caused by Pseudomonas solanacearum E.F. Smith is one of the major constraints in the production of solanaceous crops. Bacterium survives in soils for varying periods of time even in the absence of the host. ${ }^{10}$ The ability of the primary inoculum to survive during the non-crop period is therefore one of the important aspects to be considered in disease control. Survival of the pathogen may depend on the genetic and environmental factors it is subjected to. An attempt has been made to simulate a control practice based on the survival of $P$. solanacearum in soil under control conditions.

\section{Materials and Methods}

Highly virulent isolate of Pseudomonas solanacearum E.F. Smith biotype 3 sensu Hayward was used throughout these experiments. Pathogen was isolated from potato and its pathogenicity to potato plants was confirmed by stem and soil inoculation.

The nutrient medium used for the isolation of the bacterium and its routine culture was glucose peptone agar(Glucose $5.0 \mathrm{~g}$, Peptone $5.0 \mathrm{~g}$, Yeast extract $2.0 \mathrm{~g}$, $\mathrm{KHPO}_{4} 0.2 \mathrm{~g}, \mathrm{MgSO}_{4} .7 \mathrm{H}_{2} \mathrm{O} 0.2 \mathrm{~g}, \mathrm{CaCO}_{3} 0.1 \mathrm{~g}$, Agar $18.0 \mathrm{~g}$ in 1 litre of distilled 
water). Virulence of the isolates were maintained by passing the cultures at least once in 6 weeks through tomato (Lycopersicon esculentum Mill) cv. marglobe. Cultures in agar or as suspensions in sterile distilled water were maintained at $21 \pm 1^{\circ} \mathrm{C}$ in Precision low temperature incubators.

\subsection{Pathogenicity tests}

Pathogenicity of the bacterial isolates were confirmed by re-inoculating tomato plants. Five weeks old tomato cv. Marglobe plants raised in sterile soil were stem inoculated with the bacterial suspension containing $10^{6}$ cells $/ \mathrm{ml}$. Bacterial suspension was prepared with $48 \mathrm{~h}$ cultures grown in glucose peptone agar. Three, $10 \mu 1$ drops of the suspension were placed on the axil of the third leaf from the top and the stem was then pricked with a syringe needle (gauge 25 ) through the inoculum drop.

Inoculated plants were placed in a green house $\left(24^{\circ} \mathrm{C}\right.$ night $28-33^{\circ} \mathrm{C}$ day). Plants were observed for the wilt and yellowing after three days from inoculation.

\subsection{Evaluation of control measures}

Cultivars of popular solanaceous crops were screened for resistance to $P$. solanacearum infection. Plants were inoculated either directly by stem inoculation or by transplanting into soil inoculated with $P$. solanacearum. In the latter to each plastic pot (diameter $15.5 \mathrm{~cm}$ ) filled with $1.3 \mathrm{~kg}$ of sand loam soil (about $550 \mathrm{ml}$ ), $25 \mathrm{ml}$ of $P$. solanacearum suspension $10^{8}$ cells $/ \mathrm{ml}$ was added. Soils were mixed thoroughly and left in the green house for three days before transplanting the test plants. Host plants used were tomato (Lycopersicon esculentum Mill.) cv. Marglobe, Katugastota selection and cvs. AVRDC selection No. CL 141.0.10.3, CL 113.2.4, CL 1561.6.0. 22.4, CL 1591.5.0.1.6, CL 1591.5.0.1.7, CL 1094, F $4^{-57, C L ~ 11 d .0 .12 .1, ~ L 1 ~ a n d ~}$ L 387. Egg plant (Solanum melongenae) cv. SM 164, Chilli (Capsicum annuum). cv. MI 1, (Capsicum annuum var. grossum) cv. CA 8, Potato (Solanum tuberosum).

\subsection{Chemical and cultural methods}

A sand loam soil collected from virgin land under a thick cover of grass near Meewatura research station of the Faculty of Agriculture was used. The physical analysis of soil reveals the following mechanical composition. Sand $75.40 \%$, silt $10.32 \%$, clay $14.32 \%$ and $\mathrm{C}=3.05 \%$. The soil was passed through a $2 \mathrm{~mm}$ sieve (End Cott. Ltd., London) prior to inoculation with $P$. solanacearum. Soil was inoculated as described above.

Inoculated pots were left in the green house for five days before transplanting five tomato cv. Marglobe seedlings raised in moist heat sterilized soil. One month after transplanting dead plant material was incorporated back into soil to develop "sick" soil. Pots were later emptied and the soil was mixed thoroughly before refilling the pots with "sick soil" for experimentation. 
The pot trial consists of eight treatments. Each treatment was replicated five times. To each plastic pot (diameter $15.5 \mathrm{~cm}$ ) $1.3 \mathrm{~kg}$ of "sick" soil was added.

In organic manure treatments $26 \mathrm{~g}$ of either sun-dried cattle manure, poultry manure or leaves of Gliricidia maculata was added to each pot. Two fungicides Captan and Benlate were used in addition to lime and acetic acid as chemical treatments. To each pot either $0.5 \mathrm{~g}$ in $100 \mathrm{ml}$ of Captan (a.i. N-trichloro methyl thio tetrahydrophthalimide), $0.3 \mathrm{~g}$ in $100 \mathrm{ml}$ water of Benlate (Dupont, Methyl (1-butylcarbamoyl) benzimidazol -2-ylcarbamate or Benomyl), $15 \mathrm{~g}$ of $\mathrm{CaCO}_{3}$ or $25 \mathrm{ml}$ of $10 \%$ acetic acid was added. Inoculated and uninoculated controls were used. Five weeks old tomato $\mathrm{cv}$. Marglobe was transplanted as a test plant. Each treatment was replicated five times and pots were kept in the green house in completely randomized design.

\subsection{Quantitative assessment of microflora}

Population levels of Aspergillus sp., Penicillitum, sp., Pythium, Trichoderma and $P$. solanacearum were estimated.

Five soil samples were taken from each pot at two weeks interval for 2 months using a No. 5 cork borer. Samples from all the pots were bulked together to form a composite sample. These samples were collected in polypropylene wide neck bottles and mixed by agitating on a Vortex Genie mixer before taking sub samples for the preparation of soil suspensions. Five sub samples were taken from each composite sample using No. 1 cork borer. This soil was used to make soil dilution $10^{4}(\mathrm{w} / \mathrm{v})$ in sterile distilled water.

Population of Aspergillus spp., Trichoderma spp., and other fungi were estimated by the dilution plate technique using Martin's medium. ${ }^{11}$ One $\mathrm{ml}$ aliquots from the soil dilution $\left(1: 10^{4}\right)$ were pipetted into sterile petri dishes followed by $10 \mathrm{ml}$ autoclaved Martin's medium to each plate and the soil suspension was mixed thoroughly with melted agar by swirling the freshly poured plates. Plates were incubated at $25^{\circ} \mathrm{C}$ in Precision low temperature incubator for 5-7 days and number of colonies of Aspergillus spp., Penicillium spp., Trichoderma spp. and other fungi were counted. Different species were identified by the characters described by Barnett ${ }^{3}$ and Gilman. ${ }^{7}$

Population of actinomycetes were estimated by procedure adopted by William and Cross. ${ }^{18}$ Inoculated plates were incubated for $8-10$ days at $25^{\circ} \mathrm{C}$ before counting the number of actinomycital colonies per plate.

The survival of $P$. solanacearum in soils under different treatments was studied by monitoring the population levels at 3 weeks intervals. Selective medium proposed by Karganilla and Buddenhagen ${ }^{9}$ was used for the estimation of the bacterial 
populations. Colony counts as an average of five replicates at $10^{-4}$ dilution were recorded. Number of tomato cv. Marglobe plants wilted as percentage was recorded as estimates of pathogenicity.

\section{Results and Discussion}

Results of the pathogenicity tests showed that all cultivated varieties of Solanacea except chilli (pepper) cv. MI 1 are susceptible to $P$. solanacearum infection. Although initial symptoms of wilt appeared on the 3rd day after axil inoculation in most susceptible cultivars of the crops tested $100 \%$ wilt was recorded at a very early stage in commonly cultivated potato variety Arka 1 (Figure 1).

All the improved cultivars of tomato supplied by AVRDC and almost all other solanaceous crops tested were found to be susceptible to biotype 3 of $P$. solanacearum. It was found that $100 \%$ of the plants were wilted on the 13 th day after axil inoculation. Since biotype 3 has an island-wide distribution and especially in tomato growing areas ${ }^{2}$ any attempt to introduce new cultivars without proper soil sterilization or control measures will not be desirable.

Bacterial wilt thus remains potentially the most serious bacterial disease in solanaceous crops.

Effect of incorporation of organic manures and chemicals on the final disease severity in tomato plants are summarized in Table 1. There was a significant reduction in disease severity in Poultry manure treatment in comparison to control, although it remained at a high $\%$ of 40 . However all organic manure additions have increased the disease severity.

TABLE 1. Effect of various soil treatments on the population of Pseudomonas solanacearum, other bacteria and bacterial wilt of Tomato (Marglobe) plants

\begin{tabular}{|c|c|c|c|c|c|}
\hline Treatment & $p H$ & $\begin{array}{l}P . \text { solanacearum } \\
x 10^{3} / g \text { soil }\end{array}$ & $\begin{array}{l}\text { Other } \\
\text { bacteria }\end{array}$ & $\begin{array}{l}O B / P S \\
\text { ratio }\end{array}$ & $\%$ wilt \\
\hline Poultry manure & 7.5 & 11.3 & 99.6 & 10 & 40 \\
\hline Cowdung & 7.9 & 20.0 & 98.0 & 5 & 85 \\
\hline Glyricidia & 7.2 & 42.3 & 166.0 & 4 & 75 \\
\hline Lime & 7.4 & 7.0 & 126.0 & 18 & 5 \\
\hline Benlate & 7.3 & 3.6 & 60.3 & 15 & 10 \\
\hline Captan & 6.5 & 3.0 & 35.0 & 12 & 0 \\
\hline Acetic acid & 5.0 & 3.0 & 22.3 & 7 & 0 \\
\hline Control & 6.6 & 9.8 & 74.6 & 8 & 65 \\
\hline LSD at $\mathrm{P}=0.01$ & & 8.02 & 22.6 & & 5.84 \\
\hline 0.05 & & 6.05 & 18.7 & & 5.10 \\
\hline
\end{tabular}

a. Mean of 5 replicates after 9 weeks from treatments. 


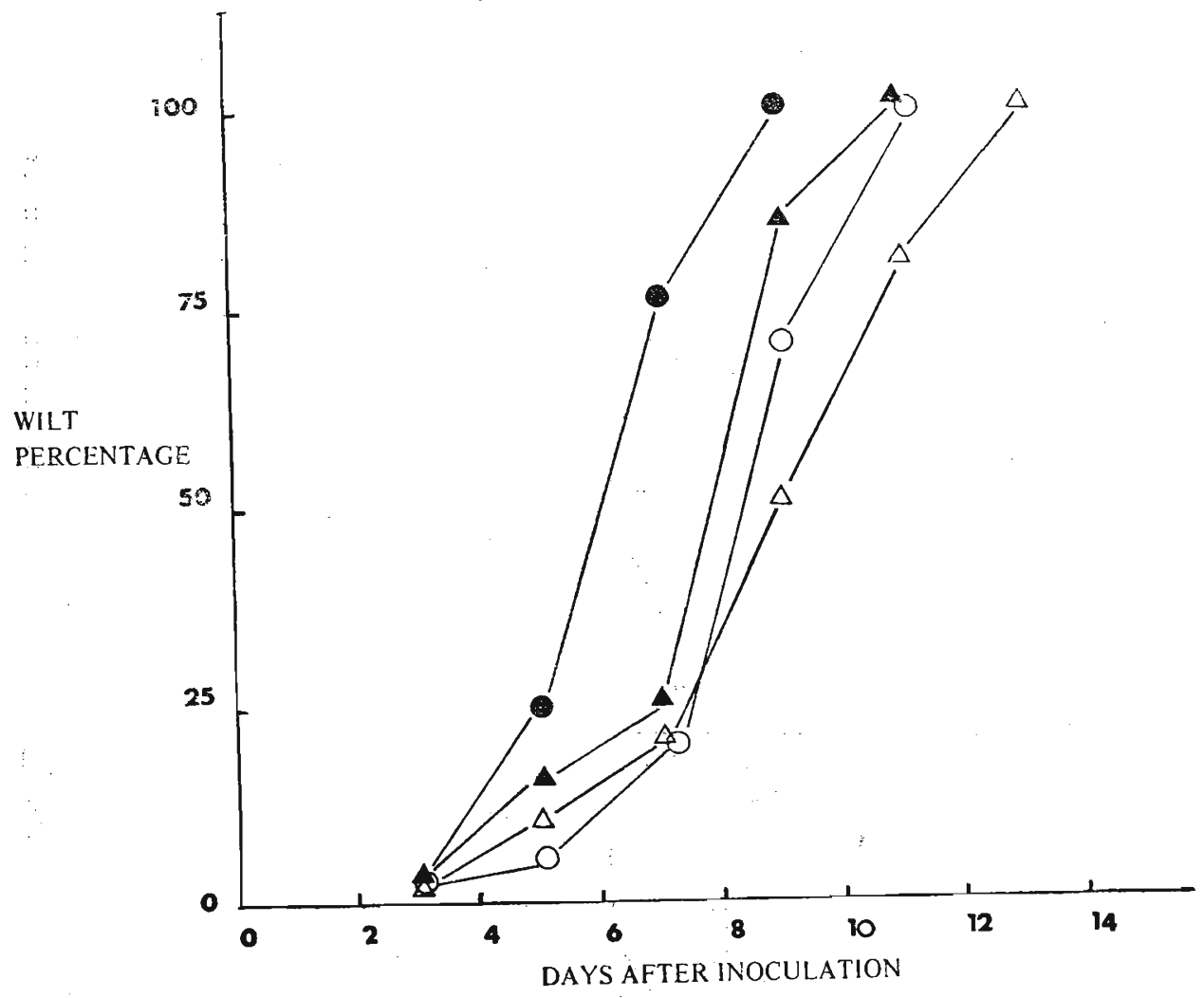

FIGURE 1 - Rate of wilting of few selected solanaceous crops artificial inoculation with Pseudomonas solanacearum (Smith) biotype III.
$\triangle$ Tomato - Marglobe
- Brinjal - SM 164
O Capsicum - CA 8
Potato - Arka 


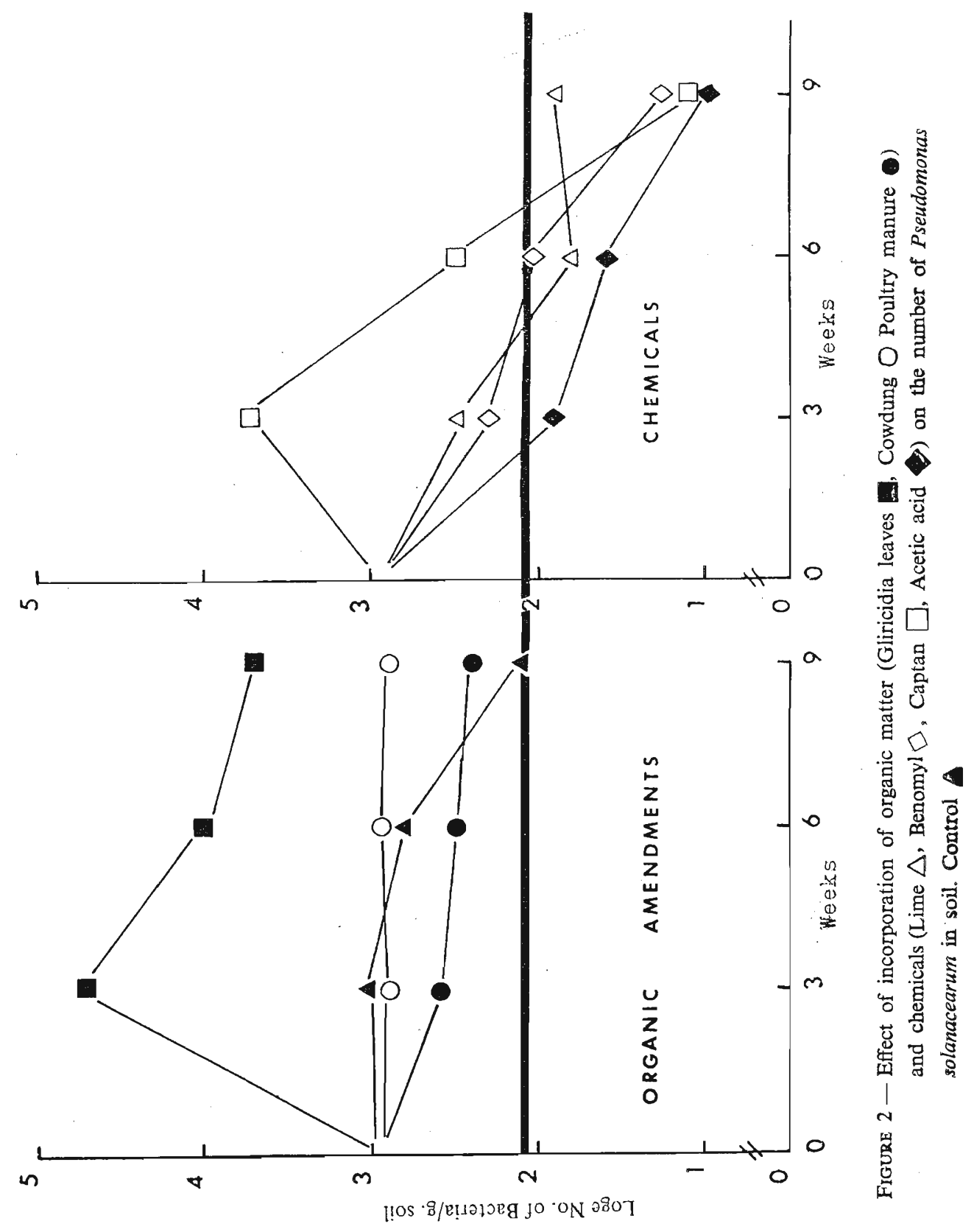


Benomyl, Captan and Acetic acid applications to soil have significantly $(\mathrm{P}=0.05)$ reduced the disease level in subsequent tomato crops. It is evident from Table 1 that $\mathrm{pH}$ had little effect in disease development. The literature concerning the importance of $\mathrm{pH}$ however is contradictory. ${ }^{10}$ In some respects it appears that the disease is more severe in soils with moderate to acid $\mathrm{pH}$ values $(\mathrm{pH}$ 5.0-5.5) but it also may be severe in alkaline soil with $\mathrm{pH} 7.0-7.5 .^{14}$

Okabe $^{13}$ reported that $P$. solanacearum reproduces in soils with a $\mathrm{pH}$ of 5.0 but that the population decreased with an increase in soil $\mathrm{pH}$. Untreated, inoculated control soil with $\mathrm{pH} 6.6$ produced $65 \%$ wilt compared to Benomyl treated or lime incorporated soils with pH 7.3 - 7.4 (Table 1). However pH changes due to organic matter incorporation had no direct relationship with percentage wilt. Okabe $^{13}$ attributed low bacterial population at $\mathrm{pH} 7.1-7.7$ to greater activity of microflora. The pH changes in organic matter incorporated soils are temporary changes and could be easily reversed to its original $\mathrm{pH}$ with time.

Since the solanaceous crops are short age irrigated and are commonly cultivated it is vital to know the behaviour of $P$. solanacearum in a short period of non crop seasons in the field. Further examinations of treated soil for the survival of $P$. solanacearum and the biology of other common microorganisms in soil revealed that addition of organic matter to soil was favourable for the multiplication and survival $P$. solanacearum (Figure 2). Table 1 shows that the change in population of other bacteria was similar to that of $P$. solanacearum. This indicates that various organic manure used in tomato-vegetable cultivation provide favourable soil environment for the multiplication of bacteria and their survival. However, it is interesting to note the ratio of $P$. solanacearum to other bacteria was directly related to the disease level. This could be due to the saprophytic competition offered by the non-pathogenic bacteria.

When the microflora was studied it was found that percentage wilt was not directly related to $P$. solanacearum in soil but its relative density in soil with respect to saprophytic bacteria (Table 1). Percentage wilt showed direct relation to other bacteria/P. solanacearum ratio (OB/PS) in all treatments except in acetic acid treated soil (Figure 3). This was probably due to extremely low pH 5.0 toxic effect of acid treatment that completely inhibited bacterial multiplication. Poultry manure in soil at $\mathrm{pH} 7.5$ gave a OB/PS ratio 10. All soils with a OB/PS ratio higher than 10 were suppressive for wilt production.

Gliricidia leaves when incorporated into soil had a boosting effect on the $\boldsymbol{P}$. solanacearum population. In almost all organic manure treatments it remains significantly higher than control even after 9 weeks. Although $P$. solanacearum 


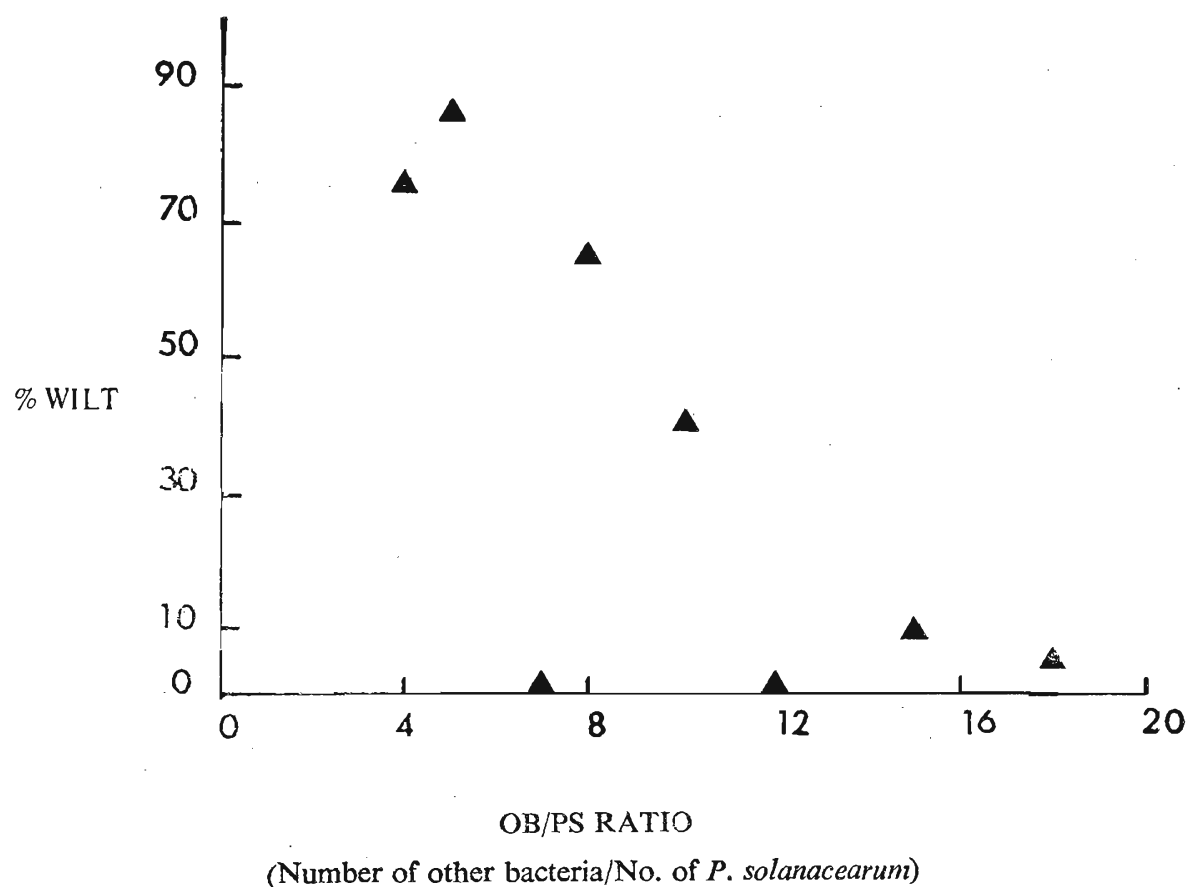

(Number of other bacteria/No. of $P$. solanacearum)

FrgURE 3 - Relationship between (No. of other bacteria/No. of Pseutomonas solanacearum OB/SP ratio and percentage wilt increased in tomato cv. Marglobe. 

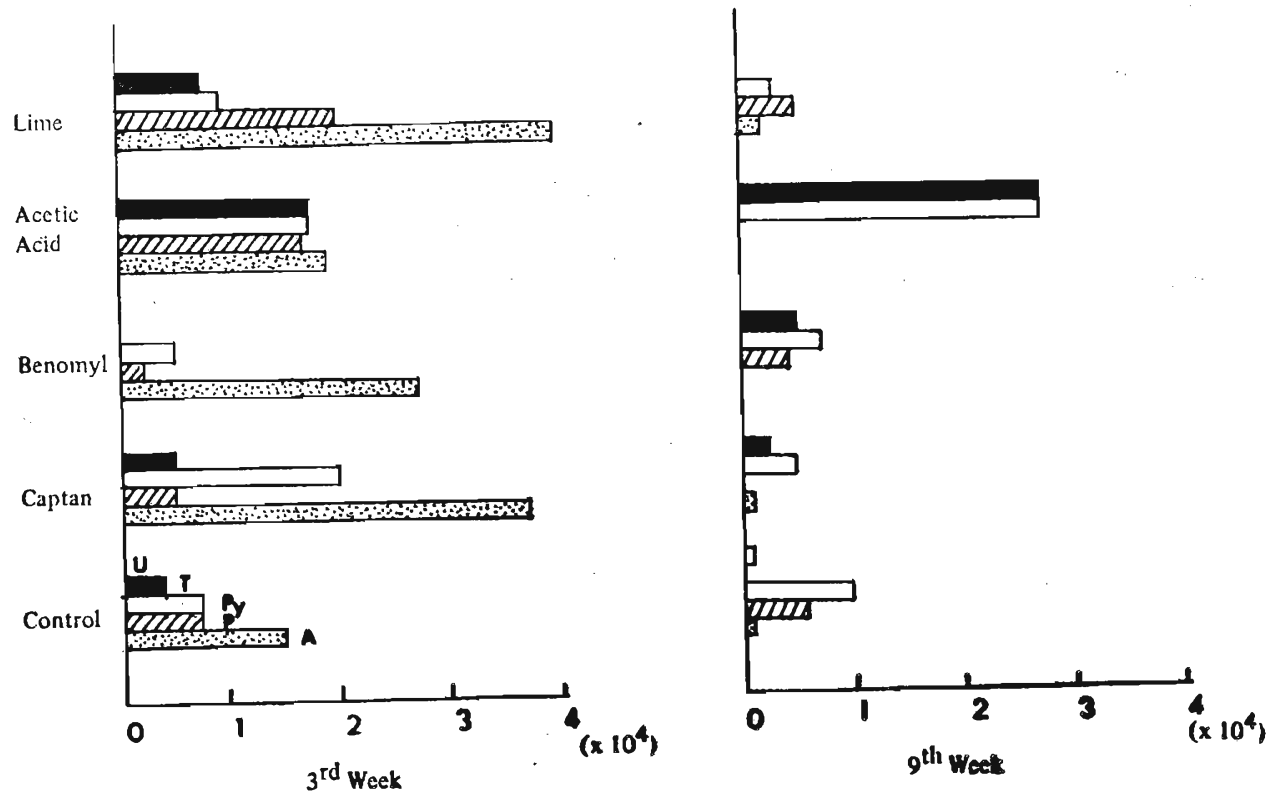

FYGURE 4 - Distribution of saprophytic fungi in soils treated with chemicals on the $3 \mathrm{rd}$ and 9 th week after treatment.
A - Aspergillus spp.
Py - Pythium spp.
P - Penicillium spp.
T - Trichoderma spp.

U - Unidentified fungi 
numbers in chemical amended soils were reduced, a significant reduction (at $\mathrm{P}=0.05$ ) was obtained only in Captan, Acetic acid and Benomyl treatments (Figure 2). Effect of acetic acid could probably be due to its low $\mathrm{pH}$ and toxicity and therefore not desirable as a control practice.

The behaviour of $P$. solanacearum population in Captan and Benomyl treatments needs further discussion. Initial increase in bacterial population in Captan treatment was very prominent (Figure 2). A Captan spray on apple leaves was reported to increase the relative abundance of bacteria. ${ }^{8}$ Subsequent reduction in $P$. solanacearum and severity $(\%)$ of wilt could be due to biological suppression/ control initiated by the chemical. ${ }^{1}$ They suggested that Captan may stimulate saprophytic Penicillium Trichorderma, Fusarium, Actinomycetes spp and bacteria. Captan was reported to be toxic to fungi, bacteria, higher plants and even insects. ${ }^{17}$ Domsch ${ }^{5}$ observed that it has no effect on bacteria. Picci ${ }^{15}$ however noted its toxic properties on nitrifying and ammonifying bacteria. Rich ${ }^{16}$ and Dienner and Carlton ${ }^{4}$ reported that Captan controls Stewarts wilt in Maize (Xanthomonas stewarti) and bacterial spot of peach respectively.

It is suggested that the reduction in $P$. solanacearum levels in soil could be due to Captan initiated biological control probably by actinomycetes or saprophytic fungi (Figure 4).

However, a gradual decline in $P$. solanacearum population was shown in Benomyl treated soil (Figure 2), which is probably due to to a direct effect on bacteria. Fassan ${ }^{6}$ stated that Benomyl had direct effect on soil bacteria and might cause shift in bacterial flora of the soil. It is also known to reduce Rhizobia in soil. ${ }^{12}$

The numerous materials and the microbial habitats available in soil to serve as energy sources provide a range of niches for plant pathogenic bacteria. Most pathogenic bacteria however could be easily displaced by more efficient nutrient utilizing saprophytes. Therefore the control of $P$. solanacearum may be achieved by selective stimulation of saprophytic population by the use of Captan or Benomyl rather than incorporation of organic matter.

\section{Acknowledgements}

I wish to express my sincere thanks to Miss S. Randombage for her helpful assistance. The financial assistance provided by the Natural Resources, Energy and Science Authority is gratefully acknowledged. 


\section{References}

1. BAKer, K. F. \& CoOK, R. J. (1974). Biological control of Plant Pathogens. 433 p. W. H. Freeman \& Co., San Francisco.

2. BANDara, J. M. R. S. (1982). Biotype distribution of Vascular wilt pathogen Pseudomonas solanacearum in Sri Lanka. J. Natn. Sci. Coun. Sri Lanka. 11 (1), 65-76.

3. Barnetr, H. L. (1960). Illustrated genera of imperfect fungi. Burges Publishing Co., U.S.A.

4. Diener, U. L. \& Carlton, C. C. (1960). Dodine - Captan combination controls bacterial spot of peach. Pl. Dis. Reptr. 44, 136-138.

5. Domsch, K. H. (1968). The effect of soil fungicide III. Quantitative changes in soil flora. Z. Pflanzenkrankh Pflanzenischutz 66, 451-456.

6. FASSEN, H. G. VAN. (1974). Effect of the fungicide Benomyl on some metabolic process and on number of bacteria in the soil. Soil Biol. Biochem. 6, 131-133.

7. Gilman, J. C. (1957). A manual of soil fungi. Iowa State University Press. 450 pp.

8. Hislop, E. C. \& Cox, T. W. (1969). Effects of Captan on the nonparasitic microflora of apple leaves. Trans. Brit. Mycol. Soc. 52: 223-235.

9. Karaganilla, A. D. \& Buddenhagen, I. W. (1972). Development of a selective medium for Pseudomonas solanacearum. Phytopathology, 62: 1373-1376.

10. Kelman, A. (1953). The bacterial wilt caused by Pseodomonas solanacearum N.C. Agric. Exp. Sta. Tech. Bull. 99: 194.

11. MARTIN, J. P. (1950). Use of acid, rose bengal and streptomycin in the plate method for estimating soil fungi. Soil Sci., 69, 215-233.

12. Narayana, Y. D., Radakrishna, D. \& Rai, P. V. (1981). Current Res., 10 (3) 47-48.

13. Okabe, N. (1971). Population changes of Pseudomonas solanacearum and soil microorganism in artificially infected natural field soil. Rev. Plant Protection Res., 4: 105-108.

14. PARK, M. \& FERNANDO, M. (1938). The relative resistance of some tomato varieties to bacterial wilt (Bacterium solanacearum F. F. Smith). Trop. Agric. (Ceylon) 91: 333-337.

15. Picci, G. (1956). Effect of Captan on soil microorganisms. Agr. Ital. (Pisa) 56, 376-382.

16. Rich, S. (1956). Seed treatments to protect corn seedling against stewarts wilt. Pl. Dis. Reptr. 40, 417-420.

17. Sosnovosky, G. (1958). The Chemistry of trichloro methane sulphenyl chloride. Chem. Rev. 58, 509-540.

18. Williams, S. T. \& Cross, T. (1974). Actinomycetes. p 298-334. In methods in microbiology Vol. 4. ed. by C. Booth. p. 795. Academic press, London. 